\title{
Tok Pisin Language
}

National Cancer Institute

\section{Source}

National Cancer Institute. Tok Pisin Language. NCI Thesaurus. Code C154174.

An English Creole language spoken as an official language in Papua New Guinea. 